\title{
PENINGKATAN HASIL BELAJAR LUAS BANGUN DATAR MELALUI PENDEKATAN CONTEXTUAL TEACHING AND LEARNING (CTL) PADA SISWA KELAS III SDN 31 LUBUK ALUNG
}

\section{Murniati}

\begin{abstract}
Abstrak
Pembelajaran luas bangun datar pada siswa SDN 31 Lubuk Alung masih bersifat konvensional. Pembelajaran masih berpusat kepada guru, sehingga membosankan bagi siswa. Untuk itu peneliti tertarik untuk memperbaiki proses pembelajaran matematika khususnya pembelajaran luas persegi dan persegi panjang melalui pendekatan Contextual Teaching and Learning (CTL). Pendekatan CTL dirasakan mampu mengatasi persoalan yang ada. Pada peningkatan hasil belajar luas persegi dan persegi panjang melalui pendekatan $C T L$ terdapat 7 langkah yaitu: konstruktivisme, inkuiri, bertanya, masyarakat belajar, pemodelan, refleksi dan penilaian otentik. Pendekatan yang digunakan dalam penelitian ini adalah pendekatan kualitatif. Data penelitian berupa informasi tentang proses dan data hasil tindakan yang diperoleh dari hasil pengamatan, hasil tes, diskusi dan dokumentasi. Sumber data adalah proses pelaksanaan pembelajaran matematika melalui pendekatan CTL di kelas III SDN 31 Lubuk Alung. Subjek peneliti terdiri dari siswa kelas III SDN 31 Lubuk Alung yang berjumlah sebanyak 29 orang. Analisis data dilakukan dengan menggunakan model analisis data. Prosedur penelitian dilakukan melalui 4 tahap yaitu 1) perencanaan 2) pelaksanaan 3) pengamatan 4) refleksi. Hasil penelitian yang dilakukan persentase rata-rata kelas hasil belajar siswa pada siklus I pertemuan 1 dengan materi luas persegi adalah $80 \%$ pada siklus I pertemuan 2 dengan materi persegi panjang adalah $69 \%$, siklus II pertemuan 1 dengan materi luas persegi dan persegi panjang adalah $97 \%$ pada siklus II pertemuan 2 adalah 98\%. Kesimpulan yang didapatkan dari penelitian ini adalah pendekatan CTL dapat meningkatkan hasil belajar luas bangun datar yaitu tentang luas persegi dan persegi panjang.
\end{abstract}

Keyword: Contextual Teaching Learning, Luas Bangun Datar

Copyright (C) 2016 IICET (Padang - Indonesia) - All Rights Reserved Indonesian Institute for Counseling, Education and Theraphy (IICET)

\section{PENDAHULUAN}

Materi mencari luas bangun datar merupakan salah satu kompetensi dasar yang harus dikuasai siswa Sekolah Dasar (SD) khususnya kelas III. Menurut Indriyastuti (2008:1751) "Luas bangun datar adalah daerah bidang datar yang dibatasi oleh garis yang mengelilinginya”. Sejalan dengan pendapat tersebut menurut Sri (2006:128) "Konsep mencari luas suatu bangun geometri dapat ditanamkan kepada siswa SD melalui kegiatan siswa". Hal ini dilakukan untuk mencegah siswa memahami konsep luas secara verbal atau hanya dengan menghafal rumus mencari luas bangun datar.

Dalam pembelajaran luas bangun datar terlebih dahulu siswa harus memahami konsep luas bangun datar beranjak dari benda-benda konkrit yang ada di lingkungan siswa. Kemudian siswa dapat memahami konsep luas bangun datar dari rumus luas bangun datar yang diajarkan guru. Agar pembelajaran luas bangun datar berhasil diperlukan suatu pendekatan pembelajaran yang dapat meningkatkan hasil belajar siswa. Salah satu pendekatan yang dapat membantu siswa untuk dapat meningkatkan pengetahuannya sesuai dengan situasi konkrit sehingga dapat meningkatkan hasil belajar luas bangun datar adalah pendekatan Contextual Teaching and Learning (CTL).

Berdasarkan hasil observasi peneliti dengan guru di kelas III SDN 31 Lubuk Alung Kabupaten Padang Pariaman bahwa dalam pembelajaran matematika tentang luas persegi dan persegi panjang masih banyak menggunakan metode ceramah dan kegiatannya lebih berpusat kepada guru. Dalam pembelajaran guru hanya membuat gambar bangun datar di papan tulis contohnya gambar persegi. Kemudian siswa diberikan rumus 
persegi adalah s x s. Jika diketahui sisi persegi tadi adalah $4 \mathrm{~cm}$. Berapakah luas persegi tersebut? Siswa menjawab soal yang diberikan guru berdasarkan rumus yang telah diberikan guru. Sehingga siswa tidak bisa membedakan mana yang diketahui, ditanya dan penyelesaian dari pembelajaran luas persegi dan persegi panjang. Hal ini dapat terlihat dari hasil belajar siswa kelas III tentang bangun datar yaitu dengan rata-rata 6,9.

Masalah penelitian ini dirumuskan sebagai berikut: "Bagaimana meningkatkan hasil belajar luas bangun datar melalui pendekatan CTL pada siswa kelas III SDN 31 Lubuk Alung Kabupaten Padang Pariaman ?’.

Penelitian ini bertujuan untuk mendeskripsikan:

1. Perencanaan pembelajaran yang dapat meningkatkan hasil belajar luas bangun datar melalui pendekatan CTL di kelas III SDN 31 Lubuk Alung Kabupaten Padang Pariaman .

2. Pelaksanaan pembelajaran yang dapat meningkatkan hasil belajar luas bangun datar melalui pendekatan CTL pada siswa kelas III SDN 31 Lubuk Alung Kabupaten Padang Pariaman.

3. Peningkatan hasil belajar luas bangun datar melalui pendekatan CTL di kelas III SDN 31 Lubuk Alung Kabupaten Padang Pariaman.

\section{METODELOGI PENELITIAN}

Penelitian ini dilaksanakan di kelas III SDN 31 Lubuk Alung. Sebagai subjek dalam penelitian ini adalah siswa kelas III SDN 31 Lubuk Alung yang terdaftar pada semester II tahun ajaran 2013/2014, dengan jumlah 29 orang yaitu perempuan 15 orang dan 14 orang laki-laki dengan seorang guru kelas. Waktu melakukan tindakan adalah pada bulan Mei sampai Juni 2009, semester Januari-Juni 2013 yang terdiri dari siklus I dan II. Lama penelitian adalah tiga bulan.

Pendekatan yang dipergunakan dalam penelitian ini adalah pendekatan kualitatif. Pendekatan ini berkenaan dengan perbaikan atau peningkatan proses pembelajaran di kelas yang diteliti. Pendekatan kualitatif digunakan karena prosedur penelitian yang menghasilkan data deskriptif berupa kata-kata tertulis atau lisan serta perilaku yang diamati dari orang-orang atau sumber informasi. Jenis penelitian yang dilaksanakan adalah Penelitian Tindakan Kelas (Classroom Action Research) yang terfokus pada upaya untuk mengubah kondisi riil sekarang kearah yang diharapkan (Improvement Oriented).

Menurut Suharsimi (2007:58) "Penelitian Tindakan Kelas (PTK) adalah penelitian tindakan (action research) yang dilakukan dengan tujuan memperbaiki mutu pembelajaran di kelasnya". Pendapat ini senada dengan Wardhani (2007:1.4) "Penelitian tindakan kelas adalah penelitian yang dilakukan oleh guru di dalam kelasnya sendiri melalui refleksi diri, dengan tujuan memperbaiki kinerjanya sebagai guru, sehingga hasil belajar siswa menjadi meningkat".

Proses penelitian tindakan merupakan proses daur ulang atau siklus. Menurut Suharsimi (2006:104) "Daur ulang dalam penelitian tindakan diawali dengan perencanaan tindakan (planning), penerapan tindakan (action), mengobservasi dan mengevaluasi proses dan hasil tindakan (observation and evaluation), dan melakukan refleksi (reflecting) dan seterusnya sampai perbaikan atau peningkatan yang diharapkan tercapai (kriteria keberhasilan)".

Menurut Kemmis Taggart (dalam Akhmad, 2009:6) proses penelitian tindakan merupakan daur ulang atau siklus yang dimulai dari aspek mengembangkan perencanaan, melakukan tindakan sesuai rencana, melakukan observasi terhadap tindakan dan melakukan refleksi. Dalam satu siklus terdapat dua kali pertemuan. Setiap akhir pertemuan dilakukan tes.

Penelitian ini di awali dengan adanya observasi terhadap proses pembelajaran luas bangun datar di SDN 31 Lubuk Alung Kabupaten Padang Pariaman. Kegiatan ini dilaksanakan untuk mengetahui permasalahan yang dihadapi berkaitan dengan proses pembelajaran luas bangun datar di kelas III SDN 31 Lubuk Alung Kabupaten Padang Pariaman..

\section{Perencanaan}

Sesuai dengan rumusan masalah hasil studi pendahuluan, peneliti berdiskusi dengan guru untuk membuat rencana tindakan yang dilakukan. Tindakan itu berupa pembelajaran luas bangun datar melalui pendekatan $C T L$. Kegiatan ini dimulai dengan merumuskan rancangan tindakan pembelajaran yaitu:

1) Menyusun rancangan berupa model satuan pembelajaran meliputi: a) tujuan pembelajaran b) memilih dan menetapkan materi c) kegiatan belajar mengajar d) memilih dan menetapkan media dan sumber pembelajaran e) evaluasi

2) Menyusun indikator, deskriptor, dan kriteria pembelajaran melalui pendekatan CTL.

3) Menyusun teknik pengumpulan data penelitian berupa: observasi, teknik tes, diskusi dan dokumentasi. 


\section{Pelaksanaan}

Praktisi melakukan kegiatan pembelajaran di kelas berupa kegiatan interaksi diantara guru dan siswa dan antara siswa dengan siswa. Kegiatan yang dilakukan antara lain:

1) Peneliti sebagai guru praktisi melaksanakan pembelajaran melalui pendekatan CTL sesuai dengan rancangan pembelajaran yang dibuat.

2) Observer melakukan pengamatan dengan menggunakan format penilaian dan lembar pengamatan

3) Penelitian dan guru melakukan diskusi terhadap tindakan yang dilakukan, kemudian melakukan refleksi. Hasilnya dimanfaatkan untuk perbaikan atau penyempurnaan selanjutnya.

\section{Pengamatan}

Pengamatan dilakukan peneliti pada waktu guru melaksanakan tindakan pembelajaran luas bangun datar. Dalam kegiatan ini guru dan peneliti berusaha mengenal, mengamati, dan mendokumentasikan semua indikator dari proses hasil perubahan yang terjadi, baik yang disebabkan oleh tindakan yang terencana maupun dampak intervensi dalam pembelajaran luas bangun datar melalui pendekatan CTL. Pengamatan dilakukan secara terus menerus mulai dari siklus I sampai siklus II.

\section{Refleksi}

Refleksi diadakan setiap satu tindakan berakhir. Dalam tahap ini guru atau praktisi dan peneliti mengadakan diskusi terhadap tindakan yang baru dilakukan. Hal-hal yang didiskusikan adalah:

1) Menganalisis tindakan yang baru dilakukan

2) Mengulas dan menjelaskan perbedaan rencana dan pelaksanaan tindakan yang telah dilakukan

3) Melakukan intervensi, pemaknaan dan penyimpulan data yang diperoleh.

4) Hasil refleksi bersama ini dimanfaatkan sebagai masukan pada tingkatan selanjutnya. Selain itu, hasil kegiatan refleksi setiap tindakan digunakan untuk menyusun simpulan terhadap hasil tindakan I dan II.

Data penelitian berupa observasi, hasil tes, diskusi dan dokumentasi dari setiap tindakan perbaikan peningkatan hasil belajar luas bangun datar melalui pendekatan CTL siswa kelas III SD yang diteliti. Data tersebut berisi tentang hal-hal yang berkaitan dengan perencanaan, pelaksanaan, dan hasil pembelajaran yang berupa informasi berikut:

1) Pelaksanaan pembelajaran yang berhubungan dengan perilaku guru dan siswa yang meliputi interaksi belajar-mengajar antara guru dan siswa, siswa dengan siswa, siswa dengan guru dalam proses pembelajaran matematika.

2) Evaluasi peningkatan hasil belajar luas bangun datar berupa evaluasi proses maupun evaluasi hasil.

3) Hasil tes siswa dilaksanakan sesudah pelaksanaan tindakan pembelajaran luas bangun datar.

Sumber data penelitian adalah proses pembelajaran luas bangun datar di kelas III SDN 31 Lubuk Alung Kabupaten Padang Pariaman .

Data penelitian ini dikumpulkan dengan observasi, hasil tes, diskusi dan dokumentasi. Untuk masingmasing akan diuraikan sebagai berikut:

a) Observasi dilakukan untuk mengamati kelas tempat berlangsungnya pembelajaran luas bangun datar.

b) Diskusi dilakukan yang berkaitan dengan pelaksanaan perencanaan pembelajaran matematika.

c) Tes di gunakan untuk memperkuat data observasi yang terjadi di dalam kelas terutama pada butir penguasaan materi pembelajaran dari unsur siswa.

d) Dokumentasi akan diambil pada saat peneliti melakukan penelitian dalam proses pembelajaran luas bangun datar dengan menggunakan pendekatan $C T L$.

Data yang diperoleh dalam penelitian menggunakan model analisis data kualitatif. Model data kualitatif oleh Miles dan Huberman (dalam Akhmad, 2009:8) yakni analisis data dimulai dengan menelaah sejak pengumpulan data sampai seluruh data terkumpul. Data tersebut direduksi berdasarkan masalah yang diteliti, diikuti penyajian data dan terakhir penyimpulan atau verifikasi.

Kemudian data tersebut direduksi melalui pengkategorian dan pengklasifikasian sesuai dengan fokus masing-masing. Dengan menyeleksi mana yang relevan dan mana yang tidak relevan. Kemudian data tersebut disajikan dengan cara mengorganisasikan informasi yang telah direduksi melalui rangkuman yang disajikan secara terpadu. Barulah terakhir dengan menyimpulkan hasil penelitian. 


\section{HASIL DAN PEMBAHASAN PENELITIAN \\ HASIL PENELITIAN \\ 1. Siklus I}

Dari segi aktivitas siswa observer mengamati bahwa masih ada siswa yang kurang aktif mengikuti pembelajaran. Pada lembar pengamatan pada aspek siswa yang dilakukan oleh observer pelaksanaan pada aspek siswa belum semua siswa mencapai standar nilai yang diharapkan.

Walaupun hasil yang dicapai pada siklus I pertemuan 1 sudah menampakkan kemajuan, baik itu dari perencanaan, pelaksanaan dan aktivitas serta hasil tes tetapi peneliti merasa belum sesuai seperti yang diharapkan, dengan materi yang tergolong mudah masih banyak juga siswa yang belum memahaminya dengan baik sehingga masih terdapat siswa yang belum tuntas. Terutama sekali ada beberapa langkahlangkah dalam pelaksanaan pendekatan $C T L$ dan aktivitas siswa selama pembelajaran luas bangun datar yang persentasenya sangat kecil. Peneliti berkeinginan siswa lebih aktif dan tertarik, lebih banyak bertanya dan dapat menjawab pertanyaan guru dengan baik.

Refleksi tindakan siklus I pertemuan 2 ini mencakup refleksi terhadap perencanaan, pelaksanaan, dan hasil yang diperoleh siswa. Selama pelaksanaan tindakan dianalisis dan didiskusikan dengan observer sehingga diperoleh hal-hal sebagai berikut:

a. Kurang memotivasi siswa pada saat penguasaan materi mencari luas bangun datar sehingga siswa kurang antusias dalam menguasai materi tersebut. Penguasaan materi ini sangat berpengaruh pada perencanaan tindakan berikutnya.

b. Media kurang variatif, untuk itu perlu ditambahkan lagi pada siklus II. Karena pembelajaran belum tuntas pada siklus I pertemuan 2 maka penelitian ini dilanjutkan pada siklus II. Hasil analisis refleksi siklus I pertemuan 2 menunjukkan subjek penelitian belum mencapai tujuan pembelajaran yang diinginkan yaitu terjadinya peningkatan hasil belajar sesuai dengan persentase nilai yang diharapkan diatas $75 \%$ berdasarkan BSNP (2006:12).

\section{Siklus II}

Berdasarkan hasil refleksi pada refleksi pada siklus I, maka ditetapkan pelaksanaan siklus II. Pelaksanaan siklus II lebih ditekankan pada pemahaman siswa terhadap materi dan langkah-langkah CTL serta meningkatkan keaktifan siswa sehingga siswa dapat menyelesaikan soal luas bangun datar.

Data siklus II pertemuan 1 diketahui bahwa perencanaan pembelajaran luas persegi dan persegi panjang sudah terlaksana. Pelaksanaan pendekatan CTL pada pembelajaran luas bangun datar hasil pengamatan yang diperoleh dari perencanaan adalah peneliti telah melaksanakan proses pembelajaran sesuai dengan perencanaan, akan tetapi pelaksanaannya belum terlaksana secara menyeluruh atau sesuai dengan sistematika perencanaan yang telah dibuat.

Walaupun hasil yang dicapai pada siklus II pertemuan 1 sudah menampakkan kemajuan, baik itu dari perencanaan, pelaksanaan dan aktivitas serta hasil tes tetapi peneliti merasa belum sesuai seperti yang diharapkan. Untuk itu pembelajaran akan dilanjutkan pada siklus II pertemuan 2 sebagai penyempurnaan dari siklus II pertemuan 1.

Refleksi terhadap perencanaan yakni sebagai berikut: dilihat dari hasil paparan siklus II pertemuan 1 diketahui bahwa perencanaan pembelajaran terlaksana dengan baik. Pada siklus II pertemuan 1 peneliti memberikan materi dan siswa melakukan pembelajarannya dengan menggunakan langkah-langkah pendekatan $C T L$ untuk memperoleh data tentang hasil pelaksanaan siklus II pertemuan 1 dilakukan lembar pengamatan dan evaluasi. Selama pelaksanaan tindakan dianalisis dan didiskusikan dengan pengamat sehingga diperoleh hal-hal sebagai berikut:

a. Perlu ditingkatkan lagi cara memotivasi siswa sehingga satandar ketuntasan belajar dapat tercapai oleh siswa

b. Penggunaan media yang variatif perlu dipertahankan agar suasana pembelajaran menyenangkan

c. Hasil perolehan nilai ketuntasan siswa kurang dari target yang ditetapkan yaitu dengan ketuntasan $75 \%$ hasil ketuntasan yang diperoleh siswa adalah $97 \%$.

Pembelajaran pada siklus II pertemuan 1 ini dilanjutkan pada siklus II untuk melihat peningkatan hasil belajar sesuai dengan persentase nilai yang diharapkan diatas 75\% berdasarkan BSNP. Dari hasil yanpg didapat pada siklus kedua ini, perencanaan, pelaksanaan, hasil belajar siswa baik proses maupun hasil sudah menunjukkan bahwa penerapan pendekatan CTL telah dapat terlaksana dengan baik. Di samping itu, hasil belajar siswa pun meningkat. 


\section{PEMBAHASAN}

Dari hasil penelitian siklus I pertemuan 1 diperoleh bahwa penerapan pendekatan CTL belum terlaksana dengan baik atau yang ditargetkan, hal ini dapat terlihat dari hasil observasi selama pelaksanaan pembelajaran dan dari aktivitas siswa. Di samping itu, siswa terlihat masih kurang tertarik untuk mengikuti pembelajaran dan kurang memahami materi pembelajaran dengan baik. Hal ini terlihat ketika siswa diminta untuk menjawab pertanyaan guru, namun hanya beberapa siswa yang dapat menjawab pertanyaan dengan benar. Namun dari hasil tes yang diperoleh sudah terlihat siswa memahami materi dengan baik walaupun masih ada beberapa siswa yang mendapat nilai rendah. Hal ini dikarenakan kemampuan siswa yang berbeda-beda.

Perencanaan yang dibuat pada siklus I belum sesuai dengan pelaksanaan yang dilakukan. Ada tahap pembelajaran yang belum terlaksana secara sistematis sehingga penerapan pendekatan CTL pada siklus I ini belum terlaksana dengan baik. Pada siklus II sebaiknya pelaksanaan pembelajaran harus sistematis dengan perencanaan sehingga penerapan pendekatan CTL dapat terlaksana dengan baik.

Berdasarkan hasil pengamatan dan diskusi peneliti dengan guru kelas III, penyebab belum terlaksananya pendekatan CTL pada siklus I pertemuan I ini adalah kurang aktifnya siswa dalam proses pembelajaran, kurangnya penanaman konsep bangun datar kepada siswa. Sebaiknya penanaman konsep luas persegi dan persegi panjang disertai penggunaan media yang bervariatif sehingga siswa aktif dan tertarik untuk mengikuti proses pembelajaran.

Penyebab lain dari kurang terlaksananya pendekatan $C T L$ ini adalah guru terlalu cepat menyampaikan materi sehingga banyak siswa yang kurang memahami penjelasan guru. Berdasarkan hasil penelitian dan analisis data pada siklus I pertemuan 1 diketahui bahwa persentase perencanaan mencapai $80 \%$, persentase pelaksanaan aspek guru $83 \%$ dan aspek siswa $80 \%$, dan evaluasi proses belum menunjukkan keberhasilan dengan baik serta evaluasi hasil $80 \%$. Dengan mengerjakan soal berbentuk essay sebanyak 4 buah. Dan persentase analisis data pada siklus I pertemuan 2 perencanaan mencapai $85 \%$, persentase pelaksanaan aspek guru $69 \%$ dan aspek siswa $78 \%$, dan evaluasi proses belum menunjukkan keberhasilan dengan baik serta evaluasi hasil $69 \%$. Dengan mengerjakan soal dalam bentuk essay sebanyak 4 buah. Berdasarkan hasil pengamatan yang diperoleh pada siklus I maka direncanakan untuk melakukan siklus II dengan tujuan agar siswa lebih aktif dan tertarik untuk belajar.

Guru sebagai penggerak dan pengatur proses belajar mengajar sudah seharusnya dapat mengaktifkan semua peserta didik tanpa kecuali agar potensi yang ada pada siswa dapat tergali dan berkembang. Guru harus dapat memberikan motivasi kepada siswa dalam pembelajaran. Peran guru dalam membelajarkan siswa sangat besar, upaya menimbulkan motivasi anak untuk belajar sangat berat seperti yang diungkapkan oleh Rochman (dalam Rosna, 2006:45) bahwa: Peran guru dalam memberi motivasi anak adalah mengenal setiap siswa yang diajarkannya secara pribadi, memperlihatkan interaksi yang menyenangkan, menguasai berbagai metode dan teknik mengajar serta menggunakannya dengan tepat, menjaga suasana kelas supaya siswa terhindar dari konflik dan frustasi serta yang amat penting memperlakukan siswa sesuai dengan keadaan dan kemampuannya. Pendekatan CTL memberikan motivasi kepada siswa. Motivasi yang diberikan oleh pendekatan $C T L$ berupa kemauan berbuat lebih baik demi masa depan dalam rangka menentukan tujuan yang ingin dicapai demi peningkatan hasil belajar sehingga siswa dapat aktif dan tertarik untuk mengikuti pembelajaran. Pada siklus II diharapkan dari penerapan pendekatan CTL ini dapat terlaksana dengan baik. Untuk itu penilaian terhadap tugas siswa dengan mengerjakan pada pertemuan 1 dan 2 masing-masing 5 buah soal dalam bentuk essay. Namun hasil yang diharapkan masih banyak dari siswa kelas III yang mendapatkan nilai dibawah standar ketuntasan. Untuk itu peneliti melaksanakan siklus II sebagai perbandingan apakah pendekatan $C T L$ dapat dilaksanakan pada kelas III sekolah dasar pada pembelajaran luas persegi dan persegi panjang.

Perencanaan yang dibuat pada siklus II telah dapat terlaksana dengan baik. Pelaksanaan pembelajaran telah sistematis dengan perencanaan sehingga pembelajaran dengan pendekatan CTL pada siklus II ini telah dapat terlaksana dengan baik.

Dalam pelaksanaan pembelajaran dengan pendekatan CTL nampak siswa aktif dan semangat dalam belajar, terutama dalam proses menemukan sendiri luas persegi dan persegi panjang. Siswa bisa mengotak atik sendiri media yang telah dibawa dari rumah. Kemudian dalam hal menjawab pertanyaan, siswa sudah berani mengeluarkan pendapatnya.

Di samping itu, guru banyak memberikan kesempatan kepada siswa untuk melakukan tanya jawab, hal ini dapat terlihat ketika masing-masing kelompok melaporkan hasil diskusi dan pada saat memberikan tanggapan. Siswa telah berani melaporkan hasil diskusinya ke depan kelas dan kelompok lain memberikan tanggapan dan melakukan tanya jawab. Dengan adanya keinginan siswa untuk melaporkan hasil diskusi ke depan kelas berarti telah menunjukkan adanya keterampilan proses dalm pembelajaran luas persegi dan persegi panjang pada diri siswa. 
Terhadap siswa yang telah paham akan materi yang telah dipelajari maka guru memberikan umpan balik dan penguatan,sehingga siswa selalu termotivasi untuk belajar. Hal ini sesuai dengan pendapat Massofa (2009:1) "Penguatan yang diberikan kepada siswa menyebabkan siswa termotivasi untuk belajar, dapat mengontrol dan memotivasi perilaku yang negatif, menumbuhkan rasa percaya diri, dapat memelihara iklim kelas yang kondusif, serta dapat menyebabkan siswa terdorong untuk mengulangi atau meningkatkan perilaku yang baik tersebut".

Berdasarkan uraian di atas, maka dapat disimpulkan bahwa dengan menerapkan pendekatan CTL dapat membuat siswa tertarik dan termotivasi untuk belajar. Hal ini berarti pendekatan CTL dapat digunakan oleh guru sebagai suatu pendekatan yang baik untuk diterapkan dalam proses pembelajaran sehingga dapat mencapai tujuan yang diinginkan serta dapat menciptakan suasana belajar yang menyenangkan bagi siswa. Dari analisis penelitian siklus II pertemuan 2 nilai penerapan pendekatan CTL telah mencapai 98\% (keberhasilan sangat baik) baik perencanaan, pelaksanaan, evalusi proses dan hasil. Berdasarkan hasil yang diperoleh pada siklus II, maka pelaksanaan siklus II telah terlaksana dengan baik dan guru telah berhasil menerapkan pendekatan CTL pada pembelajaran luas persegi dan persegi panjang di kelas III SDN 31 Lubuk Alung Kabupaten Padang Pariaman.

\section{KESIMPULAN DAN SARAN}

KESIMPULAN

Berdasarkan hasil penelitian dan pembahasan maka peneliti dapat menyimpulkan sebagai berikut:

a) Perencanaan yang matang, pemilihan metode, media yang sesuai dengan materi yang diajarkan oleh guru. Perencanaan pembelajaran dengan menggunakan langkah-langkah pendekatan CTL terdiri dari 7 langkah yaitu konstruktivisme, inkuiri, bertanya, masyarakat belajar, pemodelan, refleksi dan penilaian otentik. Keseluruhan langkah pembelajaran ini terlihat pada kegiatan awal, inti dan akhir.

b) Pelaksanaan pembelajaran dengan pendekatan CTL dilaksanakan 2 siklus. Masing-masing siklus dilaksanakan 2 pertemuan. Pembelajaran dengan pendekatan CTL mempunyai 7 langkah yaitu: mengembangkan pemikiran siswa dengan cara bekerja sendiri, melaksanakan kegiatan inkuiri, mengembangkan sifat ingin tahu siswa dengan bertanya, menciptakan masyarakat belajar, menghadirkan model pembelajaran, melakukan refleksi di akhir pertemuan, melakukan penilaian sebenarnya.

c) Peningkatan hasil belajar dapat dilihat dari hasil persentase ketuntasan dan aktivitas belajar siswa melalui pendekatan CTL mencapai 98\%.

\section{SARAN}

Dari hasil penelitian yang penulis peroleh, maka peneliti mengemukakan beberapa saran yang sekiranya dapat memberikan masukan untuk peningkatan hasil belajar matematika yaitu:

a) Bagi guru hendaknya pendekatan CTL dapat dijadikan sebagai salah satu pendekatan yang dapat digunakan dalam pembelajaran luas bangun datar untuk meningkatkan hasil belajar siswa.

b) Bagi peneliti lain, yang merasa tertarik dengan pendekatan CTL agar dapat melakukan penelitian dengan menggunakan pendekatan $C T L$ dengan menggunakan materi lain.

c) Untuk pembaca, agar bagi siapa pun yang membaca tulisan ini dapat menambah wawasan kepada pembaca

\section{DAFTAR PUSTAKA}

Akhmad, Sudrajat. Pembelajaran Kontekstual. (Online)

(http://akhmadsudrajat.wordpress.com//pembelajaran-kontekstual/ diakses tanggal 28 Februari 2009)

Amelia, Roza. 2008. Penggunaan Pendekatan Kontekstual. Padang: UNP

Awidyarso. 2009. Pendekatan Kontekstual dalam http://awidyarso.files.wordpress.com diakses tanggal 28 Februari 2009.

Depdiknas. 2006. Kurikulum Tingkat Satuan Pendidikan. Jakarta: Depdiknas

Depdiknas.2007. Kamus Besar Bahasa Indonesia Edisi Ketiga. Jakarta: Balai Pustaka

Indriastuti. 2008. Dunia Matematika untuk Kelas III SD dan M. Solo: PT Tiga Serangkai Mandiri 
Johnson, Elain, B. 2008. Contextual Teaching and Learning: what it is and why it's here to stay. Bandung: MLC

Karso. 2000. Pendidikan Matematika I. Jakarta: Universitas Tebuka

Kunandar. 2007. Guru Professional Implementasi Kurukulum Tingkat Satuan Pendidikan (KTSP) dan Sukses dalam Sertifikasi Guru. Jakarta: PT Raja Grafindo Persada

Masnur, Muslich. 2007. KTSP: Dasar Pemahaman dan Pengembangan. Jakarta: Bumi Aksara

Nurhadi, dan Agus, Gerrad, Senduk. 2003. Pembelajaran Kontekstual (Contekstual Teaching And Learning/CTL) dan Penerapannya dalam KBK. Malang: UM PRESS

Sardiman, A, M. 2006. Interaksi dan Motivasi Belajar-Mengajar. Jakarta: PT Raja Grafindo Persada

Sri, Subarinah. 2006. Inovasi Pembelajaran Matematika Sekolah Dasar. Jakarta: Depdiknas

Syamsul, Hidayat. 2005. Rumus-Rumus Matematika (Berhitung). Surabaya: Apollo

Wardhani. 2007. Penelitian Tindakan Kelas. Jakarta: Universitas Terbuka 